DOI: 10.2478 /ausp-2020-0009

\title{
Ireland and the Balkans Conflict in Edna O'Brien's The Little Red Chairs
}

\author{
Orsolya SZÜCS \\ Pázmány Péter Catholic University (Budapest, Hungary) \\ Doctoral School of Literary Studies \\ orsolya.szucs@yahoo.com
}

\begin{abstract}
History has always been a major critical exploration point in Edna O'Brien's works. Notable for its realistic Irish specificity, her fiction interrogates problems of history, memory, and society with an audacious awareness. In her 2015 novel, The Little Red Chairs, O'Brien goes beyond the familiar Irish cultural context and creates a propitious alternative life-story for Radovan Karadžić, a Serbian war criminal from the Balkans conflict of the 1990s. Attending closely to the novel's factual-fictional narrative strategies and its visceral language, this essay explores how O'Brien combines stereotypical elements from the Irish contemporary reality with Eastern European sagas as well as history to then create a compelling humanitarian plotline. The novel has a particular rendering of natural elements that act as a mnemonic witness device. The essay also looks at how the landscape functions as a reflective tool, often acting as a separate "character" of the narrative.
\end{abstract}

Keywords: Ireland, Sarajevo, Karadžić, history, Edna O’Brien, Irish fiction

\section{History in Literature}

The French feminist literary critic Hélène Cixous argues that the more turbulent the historical context, the stronger is the relationship between history and works of literary fiction (Quéré 2008). This conjunction seems to be particularly apposite in the case of Ireland, where history and literature have been such close companions for so long. In 2010, Irish writer Julian Gough wrote in critical terms of this association between history and fiction, decrying Irish novelists as "a priestly caste, scribbling by candlelight, cut off from the electric current of the culture." The reason for this in Gough's view is that the majority of Irish novelists have had a "stubborn fixation with the past" (2010). Yet it is crucial to note that from the beginning of the twentieth century, Irish literary fiction adopted the task of conveying realities that often remained hidden in official, censored, Catholic Church-dominated narratives within the Irish Free State, later to become the Republic of Ireland. Fintan O’Toole 
has written of how "Irish writers acquired a paradoxical power from their roles as truth-tellers," paradoxical in the sense that they were creators of fiction (2001). Rather than Gough's "stubborn fixation with the past," O'Toole identifies a forwardlooking tendency in modern Irish literature. History and literature have been deeply intertwined in Ireland because, as a country with a traumatic colonial past, Ireland has undergone a process of what Cixous terms "history-in-the-making” (Quéré 2008, 20). In contemporary Eastern Europe, social conditions can likewise be considered as those of "history-in-the-making." In Form and Instability: Eastern Europe, Literature and Postimperial Difference, Anita Starosta observes how this region has perpetually been associated with special "anachronistic ways of thinking" and "as a derivative of Europe, [that] has an altogether distinct temporality" (2016, 3). Eastern European literature is strongly linked to its deeply disrupted history. Starosta argues that “writing about 'Eastern Europe' often entails deciphering a palimpsest of shifting borders and regional fault lines that mark its symbolic geography in order to settle its instability" $(2016,4)$.

Edna O'Brien's 2015 novel, The Little Red Chairs, brings an Irish sense of Cixous's "history-in-the-making" into dialogue with an Eastern European experience of the same phenomenon. History has always been a critical element in O'Brien's novels. Her first work, The Country Girls (1960), was originally banned in the Republic of Ireland. Her language and the social issues that she tackled were considered too challenging to the official image of a pious Irish Catholic society during the 1950s, when a deeply traditional and conservative form of Catholicism was all-pervasive in the Republic. Of the abusive father in O'Brien's novel, Declan Kiberd notes how "in a country which piously urged its young women to treat their father as a kind of god, it was subversive to depict scenes of parental violence as routine" (2018, 62). It took more than fifty years for O'Brien to receive official recognition from the Irish State. In 2015, she received a public apology from the President of Ireland, Michael D. Higgins, for the treatment that she received in her native country through the banning of her books. The President described her as a "fearless truth teller" (Vulliamy 2015). Her writing career evinces unfailing creative energy. Her works span over various historical phases and literary trends. Nonetheless, they have always managed to maintain a capricious validity. At the core of her writing is the unstinting toil of addressing and recording the reality of the world she is living in. She is a "fearless truth teller" (Vulliamy 2015) of the Irish culture but also a writer who explores religion, immigration, sexuality, the situation of women, wars, and nationalistic concerns on a global level. O'Brien began writing in an age when, as critics Claire Bracken and Tara Harney-Mahajan $(2017,4)$ observe, it was hard to "identify any literary foremothers" in Ireland. At the same time, she has maintained a continuum into the contemporary landscape of the post-Celtic Tiger era, characterized by "intensive visibility" (Bracken and Harney-Mahajan 2017, 1) of women writers who challenge neoliberal ideas. The Little Red Chairs (2015) is part 
of this innovative phase of contemporary Irish women's fiction. Although coming from an older generation, O'Brien's work can be listed alongside novels of younger writers like Eimear McBride, Sara Baume, or Anne Enright. They all question the political and cultural current of the present times while urging the need to imbue this current with greater solidarity towards the suffering of others. Edna O'Brien distinguishes between three separate periods in her writing career: the first "about myself and other women" and the second on "themes about my country, Ireland" (O'Shea 2016). She describes the recent third phase as "about the world, about the monstrous killing" (Wachtel 2016). In each phase, there is an implicit connection to homeland and to Irish culture. However, her two latest novels, The Little Red Chairs (2015) and Girl (2019), reach beyond Ireland to world historical events. Girl addresses the horror that the Boko Haram girls faced in Nigeria, while the protagonist of The Little Red Chairs is based on Radovan Karadžić, the Serbian war criminal from the Balkans conflict of the 1990s. By broadening the perspective to a global humanitarian one, O'Brien also enters into the histories of nations unfamiliar to her. This carries some of its own dangers, even if fiction has the paradoxical power to utter realities without being subject to tests of factual accuracy. Some critics claim that by focusing on micro-histories of other nations, O'Brien oversteps ethical boundaries and “is appropriating other people's stories” (Russell 2019). O’Brien has consciously ignored these objections and tackles her subjects with a great sense of responsibility, as she explained in one of her recent interviews: "the world is crying out for such stories to be told and I intend to explore them while there is a writing bone left in my body" (O’Hagan 2019).

\section{Fiction and Fact in The Little Red Chairs}

The Little Red Chairs is a novel of contemporary history based partly on events from recent Bosnian history, namely the Siege of Sarajevo at the end of the twentieth century. The male protagonist of the narrative is modelled on the Bosnian Serbian leader, Radovan Karadžić. The narrative is divided into three parts, separated by the different spatial and temporal coordinates and connected through the main heroine, Fidelma. The first part takes place in a remote village in the west of Ireland, the second in multicultural London, and the third in The Hague in The Netherlands. The novel explores the human condition through a vivid depiction of international political concerns and female experiences in global contexts. Mingled into these concerns are minor but crucial sub-plots, enriching the narrative with contemporary issues around women's rights, refugee problems, racism, rural living conditions, war, and victimhood.

The Siege of Sarajevo is considered the longest in modern history, during which half a million civilians struggled to survive (Bedford 2017). Bosnian Serb army 
troops supported by the Serbian military besieged Sarajevo on 5 April 1992. The siege lasted for almost four years. Over a quarter of a million people were stuck in a city that was bombarded from all sides. The siege ended on the 29 February 1996 , a total of 13,952 people having been killed (BBC Witness Programme 2016). One of the leaders of the Serbian troops was Radovan Karadžić. He managed to escape and hide from authorities for over thirteen years. During this time, he lived in various countries under several false names, including that of Dr Dragan David Dabic (Borger 2016). Using his training as a psychiatrist, he earned his living practising alternative medicine and became known as a "mystique healer" (Borger 2016). He was eventually caught while travelling on a bus towards Belgrade, after being closely watched and followed for several days beforehand by secret security forces. He was arrested in 2008 and held at The Hague. In 2016, he was pronounced guilty of several crimes, including genocide, ethnic cleansing, and rape. He was sentenced to forty years in prison (Rauch 2019).

Edna O'Brien conducted thorough research before writing The Little Red Chairs. She borrowed elements from Radovan's real life and consulted with experts, including Edward Vulliamy, a British reporter who was in Sarajevo during the Siege and witnessed many of the horrors (Parker 2019). Vulliamy is also one of the few journalists who had the opportunity to interview Karadžić during his trial at The Hague. It was with his help that O'Brien had the opportunity to attend some of Karadžićs trials at The Hague in person (Parker 2019). She admitted in an interview that the idea of the novel was born from a picture of the captured, long-bearded Karadzic seen in a newspaper: "I was writing about the metamorphosis from healer to killer [...] from power to the image of this healer who was taken as a 'holy' man from a bus" (Lang 2019).

In The Little Red Chairs, the character based on the real-life figure of Karadžić is a man named Dr Vlad Dragan, who escapes from Serbia to seek shelter in a small Irish mountain town called Cloonoila. The story mingles factual and fictitious details, combining first- and third-person narration. The grounding of the plot in historical reality is made evident from the very beginning. The title of the novel is the name of an artistic installation meant to commemorate the children killed during the Siege of Sarajevo in 1992 to which O'Brien refers to directly: "On the $6^{\text {th }}$ of April 2012, to commemorate the twentieth anniversary of the start of the siege of Sarajevo by Bosnian Serb forces 11,541 chairs were laid out in rows along the eight hundred metres of the Sarajevo high street. [...] Six hundred and forty-three chairs represented the children" (O'Brien 2015, 2).

The epigraphs of the novel also mingle fact and fiction. One of the quotations is from Chilean writer Roberto Bolaño: "An individual is no match for history" (O’Brien 2015, 1). O'Brien augments her narrative with a quotation from Bolaño's story By Night in Chile (Bolaño 2003) that centres on the struggle of an individual to witness and confess the horrors of modern Chilean history. O'Brien signals the vital 
importance that literature plays in uttering individual stories that are often left out from the grand narratives of history. At the same time, she aligns the Bolaño reference with another quotation taken from a Serbian saga: "The wolf is entitled to the lamb" (O'Brien 2015, 1). The "lamb" refers to the innocent victims of the Serbian war, with the wolf referring to Vlad Dragan, called the "wolf-child." Animalistic features are thus interwoven with the human, and, much like the landscape itself, the characters too resemble animals in the novel. O'Brien offers an alternative narrative of history, connecting Karadžić to Ireland as the hiding place of this criminal. The histories of Ireland and the Balkans are aligned, compared, and contrasted in the novel. As critic Dan O'Brien observes: "contemporary Ireland is implicated in the fratricidal violence of Eastern Europe" $(2019,195)$.

\section{Landscape and Character in The Little Red Chairs}

In 1984, American writer Philip Roth interviewed Edna O'Brien and described her writing as "prose like a piece of fine meshwork, a net of perfectly observed sensuous details" (Roth 1984). The opening lines of The Little Red Chairs (2015) reach out to all the senses, capturing the visual, auditory, and tactile elements of an Irish river: "The town takes its name from the river. The current, swift and dangerous, surges with a manic glee, chunks of wood and logs of ice borne along its trail. In the small sidings where water is trapped, stones, blue, black, purple, shine up out to the river bed" (O'Brien 2015, 3). The forest in her novel has its own mysterious affective language. It carries anthropomorphic characteristics of a monstrous kind. It is not some idyllic rural setting. While it resembles natural elements, it is a mystical place, a part of the world where reality is, in a way, suspended. It is as if this forest manipulates and controls its inhabitants, already suggesting through its fearsome wildness that it will be a place of dark, terrifying events. O'Brien maximizes the effects of the descriptive language by using short, focused, and precise sentences. There is a sustained paradox between the specific "understatements" of the characters in this narrative language and the visually detailed descriptions. The anticipated danger and supernatural character of the environment are accentuated by the fairytale-like style and reference to Irish folk legends: "Long afterwards there would be those who reported strange occurrences [...] The child of a gipsy family, who lived in a caravan by the sea, swore she saw the Pooka Man coming through the window at her, pointing a hatchet" (O'Brien $2015,4)$. The "Pooka" is an old Irish word for a ghost.

The influence of Nature on inhabitants is strong in The Little Red Chairs. O'Brien often starts her narratives by providing the reader with a direct landscape depiction, a clear setting that at first acts as a character in itself, without any human presence. Then the focus slowly shifts to the people who live in a locality, but in an unusual 
reversed manner: the animate world resembles the inanimate. People seem to be reflections and products of this setting, and the town itself "takes its name from the river" (O’Brien 2015, 3). Its inhabitants are myth-influenced, religious people with deep connections to the land.

After the almost poetic description of the wild, remote forces of Nature, the narrator extends the horizon to a contemporary historical one. The reader is never allowed to fully forget the exterior context, nor to be too flummoxed by the scintillating atmosphere of almost fairy-tale landscapes. O'Brien's aesthetically seductive description of the locality is balanced out by the political, historical elements that introduce the human dimension into the mysterious and compelling landscape: "Had he ventured in further, the stranger would have seen the flags of several countries, an indication of how much cosmopolitan the place has become and in a bow of nostalgia there is old farm machinery, a combine harvester, a mill wheel and a replica of an Irish cottage, when the peasants lived in hovels and ate nettles to survive" (O'Brien 2015, 3). When the mysterious stranger arrives in the town, the first connection that comes up in the discussion is the similarity of the local Irish landscape to that of the Balkans:

He heard of the beautiful scenery of Montenegro, mountains that rivalled the Alps [...] Hewn into the rocks were monasteries without windows, where people came to pray in the same way that Irish people were known to pray. Celts, he was told, had lived in the gorges of the Dolomite Mountains and along the river Dina in the centuries before Christ and the link between Ireland and the Balkans was indisputable. (O'Brien 2015, 7-8)

Thus, in the first eight pages of the novel, the reader knows little of the characters but much about the environment: the natural forces that surround and guide the characters as they emerge in the narrative. Even the name of the stranger who enters this locality is not revealed until later. We learn more about his physical appearance than his past or history. He almost perfectly blends into the fantastic, bewildering remote western Irish landscape. After the detailed descriptions of the natural elements, the omniscient narrator gradually narrows the wide focalization, arriving at the main element, the stranger: "He stays by the water's edge, apparently mesmerized by the river. Bearded in a long dark coat and white gloves, he stands on the narrow bridge" (O'Brien 2015, 8). This posture adds a feeling of anxiety to the narrative, not only in that the mysterious man with a "long, dark coat and white gloves" (O'Brien 2015, 8) appears as an uncanny element of the locality into which he enters but also through the anticipation of danger that O'Brien's slow-motion method of narrative focalization generates.

Gothic elements feature strongly in the narrative. The stranger's name, Dr Vlad Dragan, alludes to Bram Stoker's famous gothic novel and its protagonist Vlad 
Dracula. Like Dracula, Dragan also acts as a seducer, his physical beauty and charisma attracting local women, while his simple presence brings disturbance into the remote Irish village. At first, he is viewed with curiosity by the locals, who are all shocked to discover that his real nickname is the "Beast of Bosnia" (O'Brien 2015 , 128). Fidelma - a woman with whom Vlad becomes romantically involved declares that her relationship with him has brought "a terrible curse" to the village, and the child that she conceives by him is described as the "beast's child" (O'Brien 2015, 142). The locals fear that this child could become "the wayward branch of a family tree that threatens the legitimacy of the national trunk" (O'Brien 2015, 293). Dragan escapes from Eastern Europe to hide and to spread his mysterious power. Stoker's Dracula, the vampire, also leaves the safety of his homeland, which happens to be Transylvania in Eastern Europe, to spread his curse and look for new victims. Irish and Eastern European histories are thus connected in the novel not only through historical allusion but also through gothic myths.

The Irish landscape proves to be the perfect environment for a gothic villain. Its remoteness and beauty resemble the double-nature of Vlad himself. He is intelligent and mesmerizing yet, at the same time, carries a dark past, guilty of crimes against humanity. Cloonoila becomes a space devoid of civic morality: a wilderness where human-monster-animal mix in disturbing ways. The animal-human mingling is a constant element in the plot and a recurring motif in Edna O'Brien's oeuvre. The narrative of the novel shifts from third to first person, mixing dreams, surrealistic images and vivid descriptions. After his mystic portrayal, "the stranger" enters the pub, where he engages in discussion with the locals. They all seem to be captivated by the newcomer, who eventually reveals his name as Dr Vladimir Dragan, a "healer and sex therapist" (O’Brien 2015, 9). Obviously, O’Brien chooses this name for its proximity to one of the false names mentioned above, under which the real-life Karadžić travelled after the Balkans War: Dr Dragan David Dabic. The figure claims to have been brought to Ireland by a woman that appeared in his dreams. Vlad gets into several discussions with the townspeople and shows great knowledge of history, religion, and culture. His worldview clearly exceeds the limited horizon of Cloonoila village. Reality and dream keep mixing as we have the social context of the pub, while topics jump from history to mythology and folk tales. When mentioning that he came to Ireland after having a weird dream of a woman, the barman is reminded of the Irish "aisling" ("dream") poetic tradition: "one night in the monastery, there appeared to him, pale-faced and with tears streaming down her cheeks, a woman, saying I am of Ireland, entreating him to come here" (O'Brien 2015, 9). Adjectives and adverbs are not only tools for visual descriptions but are also elements of O'Brien's forensic style. The syntax is built of long, complex sentences that, in order to flow, are augmented with anticipatory, vivid adjectives and adverbs. The reader is always kept a step ahead of the characters themselves, and the constant comments of the narrator maintain an atmosphere of suspicion. 
The conversation in the pub is brief. The townspeople try to be welcoming, but Vlad mainly keeps silent and answers questions with short statements only. He tries to explain the origin of his nickname, Vuk, ${ }^{1}$ doing so with "a tentative smile" (O'Brien $2015,9)$. His name comes from a legend of a "woman who had lost several infants in succession, deciding to name her newborn Vuk, meaning wolf, because the witches who ate the babies would be too terrified to confront the wolf-child" (O'Brien 2015, 9). This animalistic element is present on every level: narrative, characters, and plot. It functions as a constant reminder of the contrast between appearances and realities in the story. The whole pub scene unfolds like a scene from a film because of its swift switch of focus from one character to the other, enriched with the account from a mystery tale of a stranger and his unknown past. The Irish characters appear only in flashes, "like members of a chorus stepping forward" (Sayers 2016). Dara, the barman, is very talkative; Mona is a widower who adores romance novels and who desperately hopes that the newcomer "will bring a bit of Romance into our lives" (O'Brien 2015, 13); Plodder policeman, Diarmuid the ex-schoolmaster; Dante "the town punk" (O'Brien 2015, 10), Ned, "who'd done time for growing marijuana in window boxes" (O’Brien 2015, 10); Desiree, “a strapping girl in her pink mini-dress bursting for news" (O’Brien 2015, 10). All members of the community are presented at the iconic place of gathering in Irish culture, the pub.

\section{Messianic Disturbance in The Little Red Chairs}

After the collapse of Ireland's economy in 2008 following a ten-year period of unprecedented financial growth that was known as the Celtic Tiger era, Ireland has slowly started to regain its economic balance up to the Covid 19 pandemic of 2020. A deep rural-urban divide remains in the country despite all the changes that it has undergone during the late twentieth/early twenty-first century, even strengthened according to depictions in O'Brien's novel. Small towns and villages have become more isolated than before, cut off from the primary centre of economic activity in the Dublin metropolitan area. This is what happens with Cloonoila in the postCeltic Tiger era in which The Little Red Chairs is set: hotels are less frequented in a country where most people find themselves burdened with financial debt. The pub is mainly frequented only by local people, shops have closed down, and any newcomer brings excitement, when tourists from all parts had been commonplace before. At the same time, Cloonoila remains a religious community in which mythology and folk beliefs still retain some measure of influence. The most important criterion of acceptance into this community is still based on the Catholic faith and one's connection with it. Vlad's status is measured by the extent of his accommodation to

1 The father of the real-life counterpart to Vlad Dragan, Radovan Karadžić, was a cobbler who was also called Vuk. 
the traditions of the Catholic faith in Ireland. In discussion with the local priest, he has to argue and defend his "profession" as a so-called "healer and sex-therapist" as well as the validity of his faith, it being Serbian Orthodox rather than Roman Catholic. The priest is uneasy with his claim to offer sexual healing, particularly since Vlad comes from a far-removed and hidden background: "The thing is - word has circulated that you intend to practice as a Sex Therapist and this is a Catholic country and chastity is our number one commandment" (O’Brien 2015, 25). It does not take too much convincing though for Father Damien to accept the newcomer, especially considering that he himself is interested in the mysterious new, modern, and "alternative" methods.

Among the other cosmopolitan citizens of the town from different backgrounds are Eastern European workers, who came to Ireland during the economic boom period of the Celtic Tiger in the early 2000s but who now struggle with integration. These characters are similarly portrayed in a panel-like description at their gathering space (the verandah), like the locals before at the pub. They all work at the local Castle, which runs as a hotel: "The kitchen staff have all gathered on the veranda, as they do most nights, for the smokers, the odd beer, to unwind. [...] They are a mixed group, Irish, Burmese, Italian, Spanish, Czech, Slovakian, Polish” (O’Brien 2015, 49). They all tell stories to each other about their lives and their cultures: fairy-tales, actual events, memories. This is what keeps this strange sub-community implicitly connected within this Irish context. Their Otherness in this Western European landscape is further strengthened by the broken English that they all use. Most of them have come with the hope of a better life: "In my small town they say Ireland good place, good wages. Homeless for one month when I arrive to Dublin. I go to one shelter and another and another, ask Can I please spend night here. (...) After two weeks I get job down in Limerick working with cows” (O’Brien 2015, 52). O’Brien provides a vivid and apt description here of current political, cultural, and social problems that operate under such false idolizations of the West. Nonetheless, the Ireland that is presented here is a very different one from that of the pre-Celtic Tiger of the twentieth century. Its ties to a patriarchal society and religion are still strong, but there are signs of a new type of community, less insular and more cross-cultural. Locating this diverse group within a local Castle, Edna O'Brien employs a gothic mirroring of Count Dracula's Castle in its Eastern European setting in Bram Stoker's 1897 novel back into the Ireland from which Stoker originated. However, the true "Count", Dragan, the Eastern Dracula, does not live here, nor does he have any interaction in the novel with those fellow Eastern European countrymen who reside and work at the Castle. The lack of communication between these workers and Vlad strengthens the image of the latter as an embodiment of a non-real, mythical, gothic hero. Everything about Vlad - including his posture, his physical appearance, and his way of speaking - is almost unearthly and in sharp contrast with the portrayal of the migrant workers from similar regions. Dr Dragan carries elements of his real-life 
counterparts, but he also strongly conforms to an old, Western tendentious stereotype of Eastern European inhabitants as evil and mysterious. This traditional stereotype has been most influential in literature through Bram Stoker's Dracula (1897). In The Little Red Chairs (2015), O’Brien maintains this stereotype by deliberately keeping Vlad apart from the other Eastern European characters.

Working at the peak of his ability, Vlad convinces everybody of his spiritual, "messianic" saviour traits. The false image will only be reversed towards the end of the novel when his blood-filled past and deeds are revealed. This strong contrast between his outward profile as a friendly healer and his hidden reality as a vicious killer highlights the profile of a psychopathic individual. It is truly frightening how these separate sides mingle throughout the narrative. He becomes amorously involved with one of the local women, a married woman called Fidelma. Her only wish is to conceive a child, living as she is in an unhappy marriage and having been through several miscarriages. Vlad refuses to help her at first and remains spiritual and distanced as a "healer" at the beginning until he breaks down and confesses to Fidelma: "I thought I could be the scientist and not the man, he said eventually [...] He put his arms around her then and said 'You are mine now, I can drown my eyes in your hair' [...] The stranger and she, like lovers now, as in a story or in a myth" (O'Brien 2015, 101). This is one of the only moments in the novel when he is portrayed as having genuine human emotions. Nonetheless, his sympathy and popularity grow steadily in the village. At a certain point, "his name is on everybody's lips, Dr Vlad this and Dr Vlad that. He has done wonders for people, women claiming to be rejuvenated just after two treatments" (O'Brien 2015, 75). To the reader, these controversial characteristics can have a dampening effect, elevating him into the position of a saviour. By giving a complex portrayal of this character, O'Brien puts the moral decision into the reader's hand to judge on the extent of evil and hope of redemption regarding Vlad. Lindsay Duguid (2015) argues that "O'Brien stands back from the narrative, allowing, collating the stories of her briefly described character without comment."

From this perspective, Vlad shares a lot in common with a character from one of O'Brien's previous works, Mich O'Kane from the novel In the Forest (2002). Like Vlad, his character is also based on a real-life counterpart, an Irishman named Brendan O'Donnell who murdered three people in a remote part of the west of Ireland in 1994 while the siege of Sarajevo entered its second year on the other side of Europe (The Irish Times 1996). Like Vlad, Mich O'Kane is also presented as both a monstrous individual and a victim of circumstances. Mich is a multinamed figure, his complex personality being reflected in the names he has been given: "The Kinderschreck. That's what the German man called him when he stole the gun. Before that he was Michen, after a saint, and then Mich, his mother's pet and then the Boy, when he went to the place, and then the Child, when Father Damien had him" (O’Brien 2002, 2). Mich was a child who had been ripped from 
his childhood after his mother's death and raised by the priest, who paradoxically is also called Father Damien. He is also called "dog" by some of the villagers with the connotation of being inferior to the other people but also preceding the figure of Dr Vlad Dragan as the wolf in O'Brien's later novel from thirteen years after In the Forest. Mich is viewed as not fully human, more a part of the non-socialized animal world. This contrasts with Vlad in The Little Red Chairs, a man whose wolflike character elevates him as strong and fearless among the villagers of Cloonoila. Yet Mich is proud of his animalistic nature, regarding himself as a son of the forest ("Caolite" in Irish) and the reincarnation of a fox. In O’Brien's portrayal of Mich's character in this light, we encounter not so much a gothic mirroring as an uncanny foresight. Mich is based upon the real-life killer Brendan O'Donnell, who ritually murdered a Catholic priest, a single woman, and her three-year-old son in a remote part of the west of Ireland. If Mich is the killer fox, Vlad is the killer wolf: the remote woodlands of rural Ireland and the Balkans territories are their hunting grounds.

At the end of In the Forest, the local doctor blames society for the fate that Mich O'Kane suffered: "The country itself was on trial, it had failed him, the system had failed him as from the age of ten he was shuttled from one institution to another, motherless, fatherless, never with them and never without them" (O'Brien 2002, 243-244). In the case of Vlad from The Little Red Chairs, society's blame is less evident as not much is revealed about Vlad's upbringing. He hints at a traumatic childhood, describing his wild, harsh, and almost insane father, who was a skilled hunter: "My father make me walk to where the wolf lies dead. Look in the eyes. Look at the flank. Now touch it. Then he made me lick the blood from my finger and he do the same" (O'Brien 2015, 94). Vlad also carries a deep resentment towards the so-called "enemy" that destroyed his culture and his people in the Balkans. After he is caught on a bus in Cloonoila (a fate similar to his real-life counterpart Karadžić), he is sent to The Hague. The last part of the novel portrays some brief snapshots of his trials, during which Vlad's spuriousness becomes evident. He does not see himself as a murderer but rather as someone acting under the laws of war: "It was only when he realized that his country and his people were about to be torn apart that he became a reluctant player. His corps never once neglected the laws of war, the legitimate customs of war" (O'Brien 2015, 263). This double vision in O'Brien's factual-fictional narratives, together with her complex visceral language, makes her writing distinctive in tone as well as authentic in rendering its topic. Her novels stretch and test the limits of moralistic understanding. The horrific events and details are revealed gradually. The landscape plays a vital role in this step-by-step structure, acting as an almost independent character of the plot. The narrative of The Little Red Chairs is mostly linear, interrupted with flashbacks into the past of the characters. The sense of hidden danger is thus strengthened by the anxiety created through the step-by-step hints about the protagonists' past and the torturous events that will be disclosed at the end. On the level of narrative 
language, these hints manifest themselves through the changes between first- and third-person narrations. The third-person level of the text is where the narrator describes everyone in the context of "appearances," where the level of normality resides. On the other hand, the interior first-person monologues and narratorial third-person comments are the arena where the fictional investigation of the chaotic workings of the mind and its desires come to the surface. What we are reading is, in fact, a mixture of a well-built realist world that crumbles underneath the hidden facets of violent animalistic compulsions when they come to the surface.

\section{Conclusion}

The link with history is a key feature in the works of Edna O'Brien. Her specific style mingles fact and fiction, often directing the attention to the inevitable interconnectedness of the two in literature. Despite the negative reception she has often received, her dissection of the hidden hypocrisies and traumas behind the official Irish landscape can be considered ground-breaking and extraordinarily brave. In her recent writings, she has turned the focus outwards, globalizing the Irish novel. She has been at the forefront of Irish women's fiction of the past sixty years and continues to be a distinguished figure of the new, contemporary phase of Irish women's writing.

By using Eastern European history as an inspiration in The Little Red Chairs, she tries to offer a new mode of engagement with the present. The novel's visceral, detail-driven language shows that certain inequalities and traumas are commonly shared among nations and cultures like those of Ireland and the Balkan territories. The factual-fictional interweaving of rural Irish and Eastern European elements highlights some of the difficulties that such collision often carries. While certain characters, such as the Eastern European guest workers at the Castle, are portrayed as maintaining the reality of this "palimpsest"-type region, the protagonist carries a lot of fictional elements from the gothic tradition. Dr Vlad Dragan is both an embodiment of the real-life Serbian war criminal and a "descendant" of Bram Stoker's Dracula (1897). The similarities with the latter are undeniably preponderant. He conforms to the old, Western stereotype of the “distant” Eastern European as uncanny and evil. In the process, O'Brien's novel creates a serendipitous narrative that stems from the Irish gothic, addresses issues of contemporary post-Celtic Tiger Ireland and the Balkans history while imbuing it all with the need for global humanitarian solidarity. 


\section{Works Cited}

BBC Witness Programme. 2016. "Surviving the Longest Siege in Modern History." 24 February. https://www.bbc.com/news/av/magazine-35604058/surviving-thelongest-siege-in-modern-history (last accessed: 20 May 2020).

Bedford, Sam. 2017. "Meet Bosnians Who Lived through the Siege of Sarajevo." The Culture Trip, 24 December. https:/theculturetrip.com/europe/bosniaherzegovina/articles/meet-bosnians-who-lived-through-the-siege-of-sarajevo/ (last accessed: 20 May 2020).

Bolaño, Roberto. 2003 [2000]. By Night in Chile. Transl. Chris Andrews. New York: New Directions.

Borger, Julian. 2016. “The Hunt for Radovan Karadžić, Ruthless Warlord Turned Spiritual Healer." The Guardian, 16 March. https://www.theguardian.com/ world/2016/mar/22/the-hunt-for-radovan-karadzic-ruthless-warlord-turnedspiritual-healer (last accessed: 20 May 2020).

Bracken, Claire and Tara Harney-Mahajan. 2017. "A Continuum of Irish Women's Writing: Reflections on the Post-Celtic Tiger Era.” Lit: Literature Interpretation Theory vol. 28, no. 1: 1-12.

Duguid, Lindsay. 2015. "Holistic Healing." The Times Literary Supplement, 18 November. https://www.the-tls.co.uk/articles/public/holistic-healing/ (last accessed: 20 May 2020).

Gough, Julian. 2010. “The State of Irish Literature.” http://www.juliangough.com/ journal/2010/2/10/the-state-of-irish-literature-2010.html (last accessed: 20 May 2020).

Kiberd, Declan. 2018. After Ireland. Writing the Nation from Beckett to the Present. Cambridge: Harvard University Press.

Lang, Kristy. 2019. “Interview with Edna O’Brien.” Radio 4, 25 August. https:// www.bbc.co.uk/programmes/m0007wss (last accessed: 25 May 2020).

O’Brien, Dan. 2019. Fine Meshwork: Edna O’Brien, Philip Roth and Irish-Jewish Literature. New York: Syracuse University Press.

O’Brien, Edna. 2002. In the Forest. New York: Houghton Mifflin Company.

2015. The Little Red Chairs. London: Faber and Faber.

2017 [1960]. The Country Girls. London: Faber and Faber.

2019. Girl. London: Faber and Faber.

O’Hagan, Sean. 2019. “Edna O’Brien: 'I Want to Go Out as Someone Who Spoke the Truth'. The Guardian, 25 August. https://www.theguardian.com/books/2019/ aug/25/edna-obrien-interview-new-novel-girl-sean-ohagan (last accessed: 20 May 2020).

O’Shea, Sinead. 2016. “Everyone Needs a Home: Edna O’Brien.” Publisher's Weekly, 11 March. https://www.publishersweekly.com/pw/by-topic/authors/profiles/ 
article/69639-everyone-needs-a-home-edna-o-brien.html (last accessed: 20 May 2020).

O'Toole, Fintan. 2001. "Writing the Boom.” The Irish Times, 15 January. http://www. irishtimes.com/culture/writing-the-boom-1.273557 (last accessed: 20 May 2020).

Parker, Ian. 2019. "Edna O’Brien Is Still Writing about Women on the Run." The New Yorker, 7 October. https://www.newyorker.com/magazine/2019/10/14/ edna-obrien-is-still-writing-about-women-on-the-run (last accessed: 25 May).

Quéré, Henri. 2008. “The Novel Today: Interview: Hélène Cixous.” In White Ink. Interviews on Sex, Text and Politics, eds. Hélène Cixous and Susan Sellers, transl. Amaleena Damlé, 15-26. Stocksfield: Acumen.

Rauch, Robert. 2019. "Radovan Karadžić.” Encyclopedia Britannica, 21 October. https://www.britannica.com/biography/Radovan-Karadzic (last accessed: 25 May).

Roth, Philip. 1984. “A Conversation with Edna O’Brien.” The New York Times, 18 November. http://movies2.nytimes.com/books/00/04/09/specials/obrien-roth. html (last accessed: 20 May 2020).

Russell, Alec. 2019. "Edna O’Brien: From Iconoclast to Icon.” Financial Times, 6 December. https://www.ft.com/content/e31a1164-15db-11ea-9ee4-11f260415385 (last accessed: 20 May 2020).

Sayers, Valeria. 2016. "The Little Red Chairs.” La Croix International, 7 September. https://international.la-croix.com/news/the-little-red-chairs/3806\# (last accessed: 20 May 2020).

Starosta, Anita. 2016. Form and Instability: Eastern Europe, Literature, Postimperial Difference. Evanston: Northwestern University Press.

Stoker, Bram. 2014 [1897]. Dracula. Dublin: Roads Publishing.

The Irish Times. 1996. "Bodies of Mother and Son (3) Were Found Ritually Slain, Murder Trial Is Told.” 16 January. https://www.irishtimes.com/news/bodies-ofmother-and-son-3-were-found-ritually-slain-murder-trial-is-told-1.22131 (last accessed: 20 May 2020).

Vulliamy, Ed. 2015. “Edna O’Brien: From Ireland's Cultural Outcast to Literary Darling." The Guardian, 10 October. https://www.theguardian.com/books/2015/ oct/10/edna-obrien-ireland-outcast-to-literary-darling (last accessed: 20 May 2020).

Wachtel, Eleanor. 2016. Radio Interview with Edna O’Brien. CBC, 16 May. https:// www.cbc.ca/news/edna-o-brien-interview-1.3581546 (last accessed: 20 May 2020). 